https://helda.helsinki.fi

\title{
The Dynamics of Ecosystems, Biodiversity Management and Social Institutions at High Northern Latitudes
}

\section{Elmqvist, T.}

Royal Swedish Academy of Sciences

2004

Elmqvist, T. et al. 2004. The Dynamics of Ecosystems, Biodiversity Management and Social Institutions at High Northern Latitudes. Ambio 33(6): 350-355.

http://hdl.handle.net/1975/270

Downloaded from Helda, University of Helsinki institutional repository.

This is an electronic reprint of the original article.

This reprint may differ from the original in pagination and typographic detail.

Please cite the original version. 


\section{The Dynamics of Ecosystems, Biodiversity Management and Social Institutions at High Northern Latitudes}

Ecosystems at high latitudes are highly dynamic, influenced by a multitude of large-scale disturbances. Due to global change processes these systems may be expected to be particularly vulnerable, affecting the sustained production of renewable wood resources and abundance of plants and animals on which local cultures depend. In this paper, we assess the implications of new understandings of high northern latitude ecosystems and what must be done to manage systems for resilience. We suggest that the focus of land management should shift from recovery from local disturbance to sustaining ecosystem functions in the face of change and disruption. The role of biodiversity as insurance for allowing a system to reorganize and develop during the disturbance and reorganization phases needs to be addressed in management and policy. We emphasize that the current concepts of ecological reserves and protected areas need to be reconsidered to developp dynamic tools for sustainable management of ecosystems in face of change. Characteristics of what may be considered as customary reserves at high latitudes are often consistent with a more dynamic view of reserves. We suggest new directions for addressing biodiversity management in dynamic landscapes at high latitudes, and provide empirical examples of insights from unconventional perspectives that may help improve the potential for sustainable management of biodiversity and the generation of ecosystem services.

\section{INTRODUCTION}

Ecosystems at high latitudes are highly dynamic, influenced by a multitude of large-scale disturbances such as fire, strong winds and flooding (1). Furthermore, due to global change processes, including melting of permafrost and change in dominant vegetation, there may be a pronounced vulnerability of natural systems due to threshold changes in ecosystem processes $(2,3)$ changing the feedback to the global climate system and affecting the sustained production of renewable wood resources and abundance of plants and animals on which local cultures depend.

Species distributions and community structures at high latitudes have been changing in response to the recent trend of warming, e.g. expansion of shrubs (4), and northward movement of the tree line (5-7), and observations by northern residents of fish and migratory birds not previously seen (8). At high latitudes the biota is species poor and decreases towards the poles, with only $3 \%$ of the global flora and $2 \%$ of the global fauna occurring in the Arctic $(9,10)$. Food chains are often short and typically there are few representatives at each level. By contrast, functional diversity is often high, although each functional group is represented by only a few species (9). Due to changes in climate and direct human impacts we may expect profound biotic changes at high latitudes (11) such as local extinction, relocation of species and establishment of new species. The properties of high lati- tude ecosystems may alter rapidly with only minor such changes in species composition, e.g. through invasions of exotic species or through removal of top predators causing overabundance of large herbivores and impoverished vegetation (12-14).

This suggests that the focus of land management should shift from recovery from local disturbance to sustaining ecosystem functions in the face of change and disruption.

The role of biodiversity as insurance for allowing a system to reorganize and develop during the disturbance and reorganization phases needs to be addressed in management and policy $(2,14-$ 16). A perspective of ecosystems as dynamic complex systems has important consequences for our current strategy for preserving biodiversity, i.e. establishing reserves and choosing management systems in the landscape $(17,18)$. The idea of "freezing" parts of a landscape for "eternity" is problematic particularly at high latitudes. Due to changing climate, reserves cannot successfully protect species unless they are functionally connected, take into account the temporal dynamics of ecosystems or have adequate interconnections to allow migration in response to climatic change. Furthermore, reserves are open systems that will sooner or later be affected by large-scale disturbances that may challenge the existence of the whole reserve system, unless it is very large. Our main point is that many reserves need not and should not be static entities, but have to be part of large-scale dynamic and adaptive management across the landscape and include both protection, management and, if needed, restoration (19). We argue that there is a need for a paradigm shift where the current strategy based on static reserves is complemented with a strategy that includes components such as dynamic reserves or refuges. Such areas are designated specifically with the goal of management of biodiversity, each area with a time-limited duration. Thus, over long time periods the refuges are spatially mobile in the landscape. Such spatial dynamics may be important as an insurance mechanism under scenarios of increasing uncertainty. Furthermore, it has been pointed out that in order for species with metapopulation dynamics to persist in a landscape, the presence of "empty habitats" suitable for colonization are crucially important (20) and dynamic reserves or refuges represent one strategy to increase the amount of "empty habitat" in the landscape (21).

However, most formal social institutions are designed to manage static preserves and there is a need for new innovative flexible institutions. There are two unconventional but promising sources of innovation for biodiversity management and the design of new social institutions: indigenous communities and resource industries. Regarding the first, the role of local communities and local ecological knowledge in the management of natural resources and ecosystems has received increasing attention in recent years (22-24). There is a largely untapped reservoir of local knowledge and practice in many high latitude regions. Strengthening local social institutions would play an important role to adapt these practices toward new purposes in dynamic and sustainable management of ecosystems (25). Regarding the second, there is a similar but largely untapped potential to work 


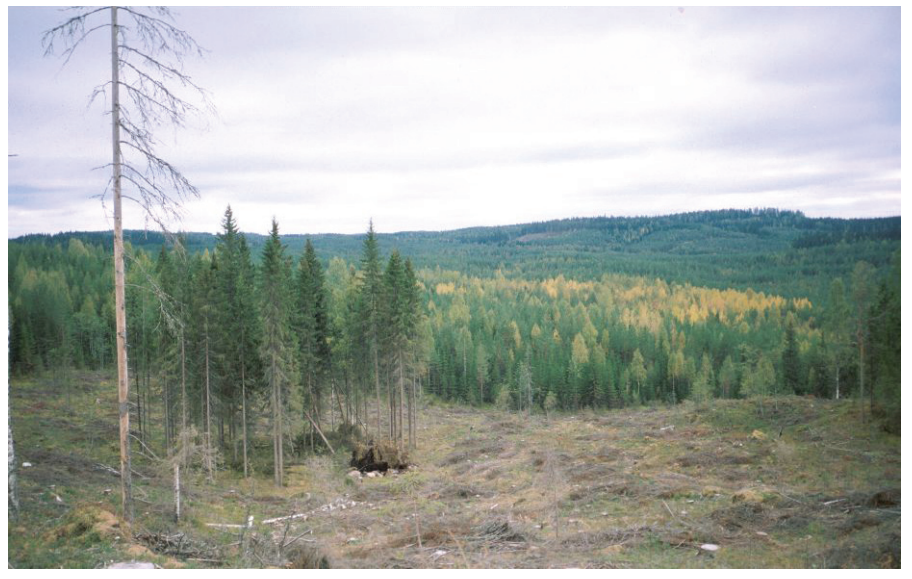

An example of green tree retention in modern Finnish forestry. Photo: K. Matveinen.

with resource industries for ecosystem and biodiversity management. Large parts of the circumpolar north are under the control of large, multinational corporations or state monopolies, as in the case of the forest industry (26) and the petroleum industry (27). While these industries do not have a sparkling record with biodiversity conservation, new international controls and certification requirements are providing strong incentives for corporate interests to become responsible world citizens (28).

In this paper, we assess the implications of new understandings of high northern latitude ecosystems and what must be done to manage systems for resilience. We suggest new directions for addressing biodiversity management in dynamic landscapes at high latitudes, and provide empirical examples of insights from unconventional perspectives that may help improve the potential for sustainable management of biodiversity and the generation of ecosystem services.

\section{ECOSYSTEM RESILIENCE AND BIODIVERSITY MAN- AGEMENT AT HIGH LATITUDES}

Ecosystem resilience has been proposed as an essential factor underlying the sustained production of natural resources and ecosystem services in complex systems faced with uncertainty and surprise (2). Ecosystem resilience is defined as the amount of disturbance a system can absorb and still remain within the same state or domain of attraction $(29,30)$. Resilience also encompasses the ability for reorganization and renewal of an ecosystem subject to disturbance and change. The definition includes the degree to which the system is capable of self-organization (versus lack of organization, or organization forced by external factors) and the degree to which the system expresses capacity for learning and adaptation (31)

Since disturbances are intrinsic parts of ecosystems, it will rarely be possible or desirable to exclude them. Natural disturbances tend to be pulse disturbances with a characteristic magnitude and frequency distribution. Human activities tend to transform pulse disturbances into press or chronic disturbances (18) and contribute to the creation of compounded perturbations (32). Sustaining desirable states of an ecosystem in the face of compounded perturbations requires among other things that functional groups of species remain available for renewal and reorganization (16). For the long-term sustainability of ecosystems and the services they generate, the preservation of biodiversity as an insurance is often viewed as necessary (33-35).

Establishment of protected areas of various types is the conventional way to protect biodiversity. Simply setting aside land as a nature reserve with the purpose to maintain it as it is without allowing for disturbance, will not secure the long-term protection of biodiversity within the reserve (18). There is usually a mismatch between the size and temporal extent of many present- day natural reserves and management systems on the one hand and natural ecosystem dynamics on the other (17). Reserves that are too small to incorporate natural disturbance regimes (36) are social constructs disconnected from ecosystem dynamics. For example, in Sweden, the median reserve size is approximately $0.2 \mathrm{~km}^{2}(37)$, which is several orders of magnitude smaller than what is needed for maintenance of specialized focal species (38). From a population biology perspective, it is the spatial population dynamics in combination with a spatially structured landscape that determine the distribution and abundance of species and ultimately their regional persistence, processes that affect design of reserves. Nevertheless, such considerations have largely been ignored, despite that sites outside a reserve network may be more important to what happens in the reserves than the reserves themselves (21).

Of the terrestrial Arctic area, protected areas cover approximately $15 \%$; however, they are unevenly distributed across ecosystems and habitats - over $27 \%$ of Arctic glaciers are protected, but less than $5 \%$ of the forest tundra $(39,40)$. Similarly in boreal forests, reserves are unevenly distributed. In Sweden, a total of $3.7 \%$ of boreal forest is protected but only $0.8 \%$ of the area used in productive boreal forestry (41).

While the small spatial extent of most reserves and national parks are frequently acknowledged (42), the limited temporal extent of most reserves has not been commonly recognized. Many small reserves may not yet have encountered the disturbances that could disrupt their dynamics and connections to the rest of the landscape. It is well known that infrequent large-scale events have affected ecosystems, but this fact has seldom been incorporated into management plans (43, see also discussion about fires in the Yellowstone National Park in Christensen et al. 44).

\section{FEASIBILITY OF DYNAMIC BIODIVERSITY MANAGE- MENT PRACTICES AT HIGH NORTHERN LATITUDES FROM A SOCIAL AND ECONOMIC PERSPECTIVE}

As a strategy for handling a more dynamic and uncertain future, Bengtsson et al. (18) suggested several forms of dynamic reserves or refuges as a vital complement to the traditional static approach. Imperative to such dynamic reserves or refuges is that they must be part of management at the landscape level, i.e. on a spatial scale of $10-100 \mathrm{~km}^{2}$ or more. Such areas are managed primarily for maintaining biodiversity and on a long-term basis they move around in the landscape. Hence, they will impose complicated restrictions on land use of single landowners, such as farmers or forest and fishery rights owners.

i) Ecological fallows; areas set aside for natural or low-intensity managed succession immediately after a disturbance event. As time goes by some management and resource utilization can be allowed, and finally the reserve will not be needed. For example, after clear-cuttings or forest fires fairly large proportions of the affected area could be left as ecological fallows for natural regeneration and succession. Selective logging of the growing and mature mixed forest by modified logging techniques could later be allowed.

ii) Ephemeral reserves; aimed at preserving species in the early succession or exploitation phases that large-scale intensive management otherwise may threatened. Such areas would be even shorter in duration. Their temporal extent should be so short that landowners clearly see when they are finished within the time of their management plans. Similä et al. (45) pointed out the importance of including such young successional stages, particularly after burning, in reserve networks due to the high presence of threatened and near-threatened species in such sites.

iii) Dynamic successional reserve; can be set aside early in the exploitation phase. Succession is allowed to continue unmanaged until the area is hit by a disturbance (release phase of the 


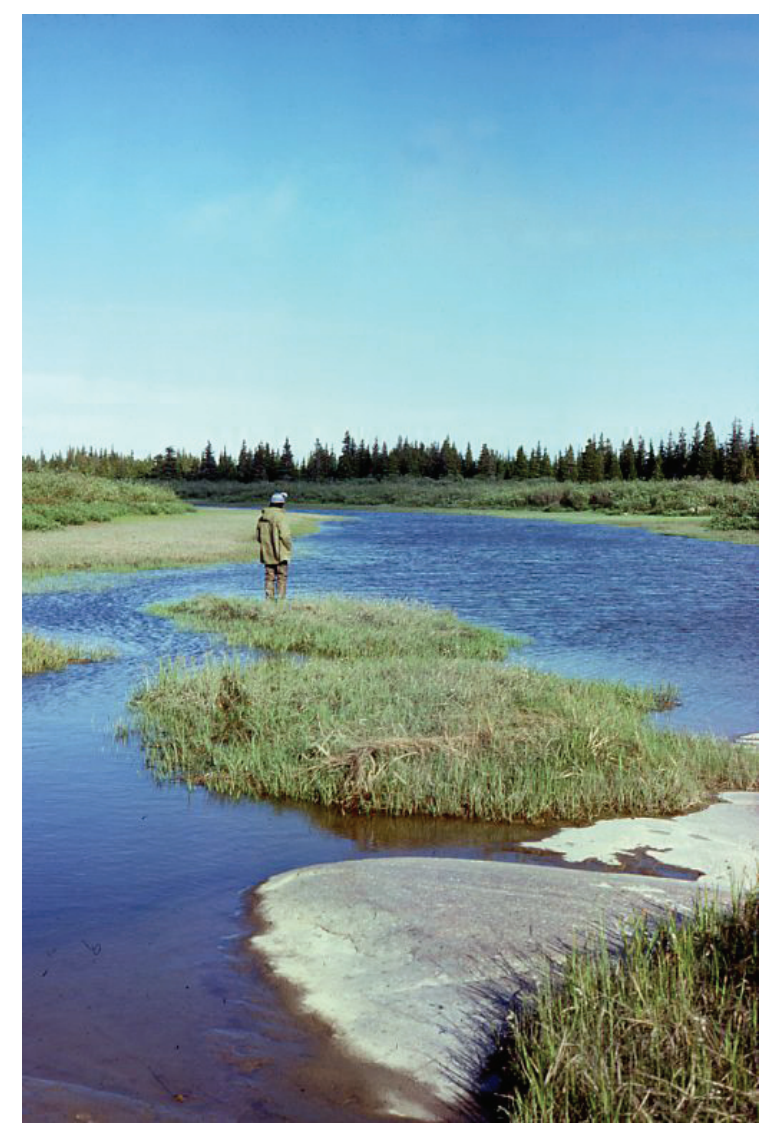

A coastal inlet near Chisasibi on the James Bay coast, northern Canada. Habitats such as this are used on a rotational basis by indigenous Cree hunters and fishers such as the Chisasibi Cree.

Photo: F. Berkes

adaptive renewal cycle), whereafter other types of management can be allowed, given that there are other areas in the landscape that provide temporal continuity.

An important issue is to what extent the creation of such dynamic biodiversity management areas at high latitudes is possible from a social and economic perspective. Much of the land at high latitudes is state property on which individuals and groups have customary or legally recognized resource use rights, so it is effectively common property $(26,46,47)$. Some of it is under the ownership of large corporations (27), and some of it under individual ownership in the more southerly parts. State, individual and common property regimes may co-exist in parts of the area, as in central Sweden (48).

The prevailing property rights regimes may complicate the design of a successful dynamic reserve program, and this can happen in one of several ways. If the establishment of the dynamic reserve results in one group obtaining benefits and other group(s) bearing the costs without getting any of the benefits, a compensation system might be necessary. If the reserve takes into account existing land and resource use practices of the local groups (see the James Bay example below), it may be possible to minimize these costs while establishing a system acceptable to all.

If the piece of land on which the reserve is supposed to rotate is distributed among many private owners (as may be the case in parts of Scandinavian countries and Alaska), then the compensation issues are worse than the case with only a few big owners controlling whole actual landscapes (49). Forcing a small owner to transform his/her property into a reserve, even for a relatively short period of time, usually leads to significant economic losses. With the conventional static reserves, the typical solution to this problem is that the authorities buy the land. With dynamic reserves, an alternative might be to compensate individual or corporate landowners for their losses during the time that their land is a reserve. Then we have a redistribution issue, with associated costs of redistribution and probably large transaction costs that must also be taken into account in the decision process.

If few owners share large parts of the total piece of land, there is a higher chance that they will be able to carry on their activities without large losses, even during the time the reserve is on part of their land. They may even benefit from it, as in the example of Canadian aboriginal goose hunters in the example below. Similarly, if the piece of land is collectively owned as common property, it could be possible for the owners to move their exploiting activities over time over the whole territory and thereby avoid exploitation in the parts that are designed as reserve. This opportunity is available if the exploiting activities do not require big and costly infrastructure and are easy to move from one place to another.

Such indigenous systems with rotational exploitation over space and time are known from many parts of the high latitudes. A well-documented example is the rotational grazing of reindeer, as practiced by the Saami people of northern Scandinavia (46, 50). Even though national borders now interfere with seasonal reindeer migrations and parts of the range may be overgrazed, the Saami reindeer system with its rotational exploitation, offers lessons for dynamic reserves. Other lessons from indigenous management systems include the renewal over-mature natural systems through fire management, as documented from the Canadian northwest (51), and a number of wildlife and fishery management systems that involve rotating areas, pulse harvesting, and maintaining multiple age-classes, as documented from the Canadian northeast (52).

\section{TRADITIONAL ECOSYSTEM MANAGEMENT AND SOCIAL INSTITUTIONS AT HIGH LATITUDES}

In this section, we provide an example of the role of local communities and local ecological knowledge in biodiversity conservation. The example provides insights on traditional management practices, and the potential of building dynamic conservation approaches based on these practices. These may be considered time-tested practices that have evolved out of the need to make a living in a difficult environment. High latitude ecosystems have a number of characteristics that make it difficult to make a living. Biological production is relatively low, resources are patchy, and resource availability is unpredictable. Environmental variability and unpredictability is perhaps greater than that elsewhere.

Peoples of the Arctic have always lived with these characteristics and have developed cultural adaptations to them. In particular, Balikci (53) notes that the capacity to adapt to extreme variability is part of Inuit culture. Hence, "dynamic and flexible use of the environment constitutes the chief adaptive strategy of Arctic communities" (54). Scholars have identified several clusters of cultural practices which are considered to be adaptive responses to the Arctic environment: $i$ ) mobility and flexibility of group size; ii) flexibility of seasonal cycles of harvest and resource use, with oral traditions providing memory; iii) detailed environmental knowledge and skill sets; and $i v$ ) sharing mechanisms and social networks for mutual support, both within and between communities (53-55).

Indigenous groups offer alternative management perspectives and knowledge based on their time-tested management practices. We assessed the international literature to examine the role of traditional ecological knowledge in monitoring, responding to and managing ecological processes and functions, with special attention to practices that build resilience. There are a diversity of local and traditional practices for ecosystem management, in- 
cluding multiple species management, resource rotation, succession management, landscape patchiness management, and ways of responding to and managing pulses and ecological surprises $(25,56)$.

Of these various classes of practices, rotational use of resource areas is one of the most pervasive. For example, among the Cree people of James Bay in the Canadian eastern subarctic, hunters rotate beaver trapping areas, often with a four-year cycle to allow populations of beaver to replenish themselves $(52,57)$. They use a similar rotation technique in moose hunting areas (58). In fishing, they monitor the declining catch per unit of effort as the feedback to relocate nets. They rotate fishing areas at two time scales, over an annual scale near the community and over a multi-year cycle for distant lakes with large whitefish, Coregonus clupeaformis (59).

Hunting and fishing areas used in rotation function like dynamic reserves since part of the land remains undisturbed for a period of time, like a fallow. Customary use does not ban hunting but it discourages continuous use that may deplete sparse populations and degrade the environment. The infrequent use of an area, for example, once every four years for beaver and once every ten years for some fishing lakes, allows for short bursts of productive harvesting, a good optimal foraging model. But it also allows for biodiversity management and sustainable use of multiple species in the ecosystem. The Cree themselves do not perceive their practices as "management", as they consider it merely the "proper way" to hunt and to show respect for the environment. An informal social institution consisting of elder hunters monitors the activities of its members and enforces the Cree concept of "good practice" by the use of social sanctions (59).

Of the various kinds of customary management practices, the one that perhaps comes closest to an ecologically designed dynamic reserve is the James Bay Cree system for goose hunting. The Chisasibi Cree are specialists in Canada goose (Branta canadensis) hunting, although they also harvest several other species of geese and ducks as well. James Bay acts like a funnel to concentrate migrating Canada geese in the fall. Hundreds of thousands of geese make feeding and resting stops in the various small bays along the east coast of James Bay. The Cree never enter these bays when the geese are feeding or staging, and never shoot into the main flocks. The traditional goose hunting spots are strategically located to intercept small groups of geese flying between feeding and staging areas. If there are too many geese, the hunters may shoo away the geese and then wait for them to return in small flocks before resuming hunting (60).

The Chisasibi Cree use a u-shaped shooting formation in the fall Canada goose hunt. The hunting group may typically include half a dozen hunters and there is a shooting order. The immediate objective is to harvest entire family units of geese cleanly and without crippling loss; the larger objective is to harvest geese without disturbing the main flocks. The Cree have elaborate rules about minimizing disturbance, for example by not shooting on calm days (because the sound carries), not making fires, and cleaning up waste (Canada geese are said to have good eyesight and will see blood on the ground). The overall success of the fall hunt depends on how many weeks the migrating flocks linger on the James Bay coast. So the immediate incentive for the Cree to regulate their hunt is harvest optimization. However, these customary dynamic reserves do also serve as areas of nondisturbance, helping maintain Canada geese populations and the other species with similar habitat requirements mixed with them (60; Berkes, unpubl. field notes).

The customary dynamic reserves of the Cree are different from existing protected areas as designated by the government. First, they are enforced solely by social custom. Second, they are reserves only during part of the year when the geese are pres- ent in large numbers; at other times, there may be people hunting and fishing in that area. Third, the boundaries of the reserve may change from year to year because the distribution of the geese changes. Hence, these customary reserves are not only dynamic in space and time, the boundary itself is flexible, responding to environmental variation and surprise.

The James Bay dynamic reserve examples are not unique. There are many examples of rotational resource use in the high latitudes, as mentioned above. The challenge is to bring together ecological science and traditional knowledge and to build on existing local institutions. To do so requires political will and the institution of co-management mechanisms. In the Canadian North, where the new system of marine protected areas has to be made consistent with aboriginal land claims agreements, innovative experiments in reserve design and co-management are underway, as in the planning for protected areas for the beluga whale Delphinapterus leucas (61).

Strengthening local-level social institutions is not by itself sufficient to institute effective co-management The challenge of combining local knowledge and government science and reconciling bottom-up and top-down approaches requires designing cross-scale management systems. These are management systems that establish institutional linkages horizontally among user-groups and geographic areas, as in the co-management of Lofoten cod (46), and vertically across the political scale, as in the case of the fight against persistent organic pollutants (62). Establishing vertical links is especially important as it is difficult to find a resource management system that does not have some cross-scale linkages and drivers at different scales (63). Globalization has a major impact on the local level, for example, through the creation of international markets for timber, impacting on forest resource use in Siberia (26).

\section{ECOSYSTEM MANAGEMENT AND BOREAL FORESTRY}

The difficulties of choosing good policy instruments for managing complex ecosystems such as boreal forests (64) was highlighted by Crépin $(65,66)$ pointing out that traditional management models for continuous harvest based on single-species models may lead to serious mismanagement and loss of resilience. Bergland et al. (unpubl.), obtained comparable results with periodic harvesting. In theory, when one cannot rely on marginal rules, one would need to calculate all future costs and benefits of each possible alternative management strategy (67). This is not realistic and creating reserves that enhance ecosystem resilience seems then to be one of the few realistic alternatives and for big forestry owners this landscape-level management strategy might even be profitable.

Although dynamic reserve strategies are far from implemented by forest companies, several landscape-level management practices of commercial forests have recently been introduced and represent complementary approaches to setting aside land for the maintenance of biodiversity. This is a promising opportunity especially in remote and low-productivity areas where the state or companies own very large tracts. For instance, in both Sweden and Finland, large forest owners are practicing a landscape approach $(49,68)$ that can be viewed as the application of biodiversity management tools across spatial scales.

In northern Sweden and Finland, where the land-use history is relatively short and land is owned mainly by large companies, the goal of boreal forest planning is to imitate the natural disturbance dynamics of the different forest ecosystems. Given the site type, forest land is stratified with respect to different disturbance regimes with the potential wildfire dynamics as a guide. This ecological landscape planning is complemented with landscape ecological planning whereby remnants of the different types of forest dynamics are set aside with the long-term goal of main- 
taining sufficient habitat connectivity. In Sweden, several large landowners have developed models for Ecological Landscape Planning (ELP), including multiple goals and spatio-temporal scales. The following activities have been defined in the landscape planning process.

i) Stratification of forests into different biogeographical regions with their characteristic past disturbance dynamics, to which the fauna and flora have evolved, and into regions with different land-use histories.

ii) Landscape analysis to estimate the physiographic and historical potential of a particular landscape to host different habitats and properties. In reality, landscapes of 5000 to 50000 ha have been analyzed, and even less for areas with high complexity, many landowners or areas that could hold viable populations of different species.

iii) Description of the present composition, structure, and processes of the selected landscape. This includes inventories of so called woodland key-biotopes, wet forests, and redlisted species.

iv) Analysis of components missing or insufficiently represented in the actual landscape to maintain or restore biodiversity.

v) Formulation of quantitative goals for each property and scale. In short, the landscape analysis is the basis for estimating the composition, structure, and processes in the original landscape. Knowledge about ecological thresholds is applied to these figures.

vi) Implementation of forest management. The Swedish system defines different management regimes, ranging from no management to intensive management with nature considerations.

vii)Control by monitoring to allow short-term steering to attain long-term goals. To be effective, monitoring of biological systems must have a sound scientific basis, be diagnostic and help understand the system, allow assessment of the stated policy objectives and, finally, include feedback to the policy process and/or management to enable midcourse corrections.

In Finland, a fairly similar approach to the Swedish model has been developed by the Finnish Forest and Park Service (Metsähallitus). This organization manages state-owned forests that predominated in eastern and northern parts of the country. During the 1990s Forest and Park Service has revised its forest planning system in order to reach the goal of sustainable forestry. The system in Finland is called 'landscape ecological planning' and covers all the silviculturally managed forest land (ca. 6.4 million ha) of the Forest and Park Service. The aim is to make sure that forests are managed sustainably from economic, ecological and sociocultural point of view. The goal of the landscape ecological planning is to ensure that logging does not result in species losses, i.e. the natural biodiversity of the area should be maintained. Scientifically, the method is loosely based on the island biogeography theory including emphasis on ecological corridors. Participatory planning involving local stakeholders is an integral part of Forest and Park Service's planning system. Various stakeholders, such as local residents (the Saami people) and environmental groups are involved in the planning process.

Planning occurs at landscape level, and stand level. The planning method aims at integrating biodiversity maintenance in commercial forests with the existing reserves. This requires knowledge about ecologically valuable sites, such as old-growth forests, springs and brooks. Valuable sites are set aside and ecological corridors are created through the managed forest to connect larger patches of high-value forest or existing protected areas. Prescribed burning is used to create habitat for pyrophilous species, and restoration is practiced to recreate habitats already lost. Such a management area creates a forest landscape quite different from a traditional managed landscape where the cut blocks have large and uniform shapes. Ecological corridors and the protection of key habitats help maintain or even increase diversity. About $10 \%$ of forests in the planning areas will be entirely or partially set aside and the amount of retention trees (both dead and alive) will increase in harvested stands. The decreased logging possibilities cause a $10-12 \%$ reduction in economic output during the first 10-20 years compared to a management strategy that only follows the restrictions in the forestry law. However, the long-term decrease in logging revenue is expected to be much less.

\section{CONCLUSION}

In the future, we can expect profound ecological changes at high latitudes and we argue that the focus of management of ecosystems should shift from recovery from local disturbance to sustaining ecosystem functions in the face of change and disruption. As part of this strategy we emphasize the need for a paradigm shift toward complementing existing static reserves with dynamic reserves and landscape-level planning of resource use in the management of high altitude ecosystems. Dynamic reserves may include management practices such as ecological fallows, ephemeral reserves and dynamic successional reserves (18), as well as an emphasis on buffer zones and networks of connecting corridors, etc. As highlighted here, customary reserves at high latitudes may often share these characteristic management practices i.e. boundaries are often flexible, responding to environmental variation and surprise. Such areas may be similar in function to "no-take reserves" recently suggested as part of a strategy for a sustainable marine fishery (69). An interesting complementary approach is the concept of buffer zones which are used worldwide in biosphere reserves (70) and around various types of protected areas in Europe $(71,72)$. However, few studies have evaluated buffers in forest habitats in the Northern Hemisphere, and comprehensive studies on this subject are rare (73).

The Finnish and Swedish experiences show that rather rapid and relatively profound changes in boreal forestry practices are possible. In both countries, major changes towards ecologically sustainable forestry took place during the 1990s. For instance, in just 6 years the Finnish Forest and Park Service prepared more than 100 landscape ecological plans covering 6 million ha. However, it is too early to conclude whether or not the plans guarantee the maintenance of biodiversity in the managed forests in Finland and Sweden.

To involve the people of high latitudes in the creation and maintenance of dynamic reserves or refuges, new co-management arrangements are needed, building on some of the above experience with cross-scale management. Co-management may consist of networks of problem-solvers (74), often involving cross-scale linkages across levels of political organization (63). Such cross-scale linkages, from the community to the international level, are not totally new at high latitudes. They have been successfully created, for example, in response to the persistent organic pollutants (POPs) issue (62). Once created, cross-scale management mechanisms can be applied to other problem areas as well, for example, to climate change (75). In areas experiencing rapid change such at high latitudes, there is a need to develop the capacity to respond and adapt to change, and to explore policy directions that can help build adaptive capacity to deal with change. The evolution of cross-scale institutions in some areas of environmental management is consistent with the call for the creation of flexible multi-level governance systems that can learn from experience and generate knowledge to cope with change (76). 


\section{References and Notes}

1. Goldammer, J.G. and Furyaev, V.V. 1996. Fire in Ecosystems of Boreal Eurasia: Ecological Impacts and Links to the Global System. International Scientific Conference on logical Impacts and Links to the Global System.
Fire in Ecosystems of Boreal Eurasia, pp. 1-20.

2. Gunderson, L.H. and Holling, C.S. (eds). 2002. Panarchy: Understanding Transformations in Systems of Humans and Nature. Island Press, Washington, DC.

3. Scheffer M. Carpenter, S.R., Foley, J., Folke, C. and Walker, B. 2001. Catastrophic shifts in ecosystems. Nature 413, 591-696.

4. Sturm, M., Racine, C. and Tape, K. 2001. Increasing shrub abundance in the Arctic Nature 411, 546-547.

5. Pastor, J. and Post, W.M. 1988. Response of northern forests to $\mathrm{CO}_{2}$-induced climate change. Nature 334, 55-58.

6. Callaghan, T.V., Werkman, B.R. and Crawford, R.M.M. 2002. The tundra-taiga interface and its dynamics: Concepts and applications. Ambio Special Report 12, 6-14

7. Lloyd, A.H., Yoshikawa, K., Fastie, C.L., Hinzman, L. and Fraver, M. 2003. Effects of permafrost degradation on woody vegetation at arctic treeline on the Seward Peninsula, Alaska. Permafrost Periglacial Processes 14, 1002-1446.

8. Berkes, F. and Jolly, D. 2001. Adapting to climate change: Social-ecological resilience in a Canadian western Arctic community. Conserv. Ecol. 5, 18. (http://www. consecol.org/vol5/iss2/art18)

9. Heywood, V.H. (ed.). 1995. Global Biodiversity Assessment. UNEP, Cambridge University Press, Cambridge, UK

10. Chapin, F.S., III and Danell, K. 2001. Boreal forest. In: Global Biodiversity in a Changing Environment: Scenarios for the 21 st Century. Chapin, F.S. III, Sala, O.E. and Hubering Environment: Scenarios for the 21st Century. Chapin, F.S.
Sannwald, E. (eds). Springer-Verlag, New York. pp. 101-120

Sannwald, E. (eds). Springer-Verlag, New York. pp. 101-120.
11. Chapin, F.S. III, et al. 2004. Resilience and vulnerability of Northern regions to social Chapin, F.S. III, et al. 2004. Resilience and vuln
and environmental change. Ambio 33, 344-349.

12. Angelstam, P., Wikberg, P.E., Danilov, P., Faber, W.E. and Nygrén, K. 2000. Effects of moose density on timber quality and biodiversity restoration in Sweden, Finland and Russian Karelia. Alces 36, 133-145

13. Berger, J., Stacey, P.B., Bellis, L. and Johnson, M.P. 2001. A mammalian predator-prey imbalance: grizzly bear and wolf extinction affect avian neotropical migrants. Ecol. Applic. 11, 947-960.

14. Angelstam, P. 2002. Large mammals, people, and the landscape - can trophic interactions be managed? In: Wildlife, Land and People: Priorities for the $21^{s t}$ Century. Field, R., Warren, R.L., Okarma, H. and Sievert, P.R. The Wildlife Society, Bethesheda, pp. 54-59.

15. Peterson. G., Allen C.R. and Holling, C.S. 1998. Ecological resilience, biodiversity, and scale. Ecosystems 1, 6-18.

16. Elmqvist, T., Folke, C., Nyström, M., Peterson, G., Bengtsson, J., Walker, B. and Norberg, J. 2003. Response diversity, ecosystem change, and resilience. Front. Ecol Environ. $1,488-494$

17. Angelstam, P. 2002. Reconciling the linkages of land management with natural disturbance regimes to maintain forest biodiversity in Europe. In: Landscape Ecology and Resource Management: Linking Theory with Practice. Bissonette, J.A. and Storch, I. Resource Management: Linking Theory with Practice. Bisson.
(eds). Island Press, Covelo and Washington, DC., pp. 193-226.

18. Bengtsson, J., Angelstam, P., Elmqvist, T., Emanuelsson, U., Folke, C., Ihse, M., Moberg, F. and Nyström, M. 2003. Reserves, resilience and dynamic landscapes. Ambio 32, 389-396.

19. Angelstam, P., Boutin, S., Schmiegelow, F., Villard, M.-A., Drapeau, P., Host, G., Innes, J., Isachenko, G., Kuuluvainen, M., Mönkkönen, M., Niemelä, J., Niemi, G., Roberge, J.-M., Spence, J. and Stone, D. 2004. Performance targets for boreal forest biodiversity conservation - a rationale for macroecological international research and adaptive management. Ecol. Bull. 51

20. Hanski, I. 1999. Metapopulation Ecology. Oxford series in ecology and evolution. Oxford University Press, New York, pp. xx-xx.

21. Cabeza, M. and Moilanen, A. 2003. Site-selection algorithms and habitat loss. Conserv Biol. 17, 1402-1413.

22. Berkes, F. and C. Folke, (eds). 1998. Linking Social and Ecological Systems. Management Practices and Social Mechanisms for Building Resilience. Cambridge University Press, Cambridge.

23. Huntington, H.P. 2000. Using traditional ecological knowledge in science: methods and applications. Ecol. Applic. 5, 1270-1274.

24. Olsson, P. and Folke, C. 2001. Local ecological knowledge and institutional dynamics for ecosystem management: A study of Lake Racken watershed, Sweden. Ecosystems 4,

25. Berkes, F., Colding, J. and Folke, C. 2000. Rediscovery of traditional ecological knowledge as adaptive management. Ecol. Applic. 10,1251-1262.

26. Carlsson, L. 2000. Towards a sustainable Russian forest sector. Nat. Res. Forum 24 31-37.

27. Forbes, B. 1999. Reindeer herding and petroleum development on Poluostrov Yamal sustainable or mutually incompatible uses? Polar Record 35, 317-322

28. Whiteman, G., Forbes, B.C., Niemelä, J. and Chapin, F.S. III. 2004. Bringing Feedback and Resilience of High-Latitude Ecosystems into the Corporate Boardroom. Ambio 33 , 371-376.

29. Holling, C.S. 1973. Resilience and stability of ecological systems. Ann. Rev. Ecol. Syst. $4,1-23$

30. Holling, C.S. 1996. Engineering resilience versus ecological resilience. In: Engineering within Ecological Constraints. Schulze P.C. (ed). National Academy Press, Washington DC

31. Carpenter, S.R., Walker, B, Anderies, J.M. and Abel, N. 2001. From metaphor to measurement: resilience of what to what? Ecosystems 4, 765-78

32. Paine, R.T., Tegner, M.J. and Johnson, E.A. 1998. Compounded perturbations yield ecological surprises. Ecosystems 1,535-545.

33. Folke, C., Holling, C.S. and Perrings, C. 1996. Biological diversity, ecosystems and the human scale. Ecol. Applic. 6, 1018-1024.

34. Naeem, S. 1998. Species redundancy and ecosystem reliability. Cons. Biol. 12, 39-45

35. Loreau, M., Naeem, S. and Inchausti, P. (eds). 2002. Biodiversity and Ecosystem Functioning: Synthesis and Perspectives. Oxford University Press, Oxford.

36. Pickett, S.T.A. and Thompson, J.N. 1978. Patch dynamics and the design of nature rePickett, S.T.A. and Thompson, J.

37. Nilsson, C. and Götmark, F. 1992. Protected areas in Sweden: Is natural variety adequately represented? Cons. Biol. 6, 232-242.

38. Angelstam, P., Roberge, J.M., Lõhmus, A., Bergmanis, M., Brazaitis, G., Breuss, M., Edenius, L., Kosinski, Z., Kurlavicius, P., Lārmanis, V., Lūkins, M., Mikusinski, G., Račinskis E., Strazds, M. and Tryjanowski, P. 2004. Habitat modelling as a tool for landscapescale conservation - a review of parameters for focal forest birds. Ecol. Bull. 5 .

39. CAff 1997. Co-operative Strategy for the Conservation of Biological Diversity in the Arctic Region. Conservation of Arctic Flora and Fauna International Secretariat, Reykavik.

40. CAFF 2001. Arctic Flora and Fauna: Status and Conservation. Edita Helsinki.

41. Hallanaro, E.L. and Pylvänäinen, M. 2001. Nature in Northern Europe: Biodiversity in a Changing Environment. Nordic Councils of Ministers, Nord 13.

42. Soulé, M.E., Wilcox, B.A. and Holtby, C. 1979. Benign neglect: a model of faunal collapse in the game reserves of East Africa. Biol. Conserv. 15, 259-272

43. Dale, V.H., Lugo, A.E., MacMahon, J.A. and Pickett, S.T.A. 1998. Ecosystem management in the context of large, infrequent disturbances. Ecosystems 1, 546-557.
44. Christensen, N.L., et al. 1989. Interpreting the Yellowstone fires of 1988. BioScience 39, 678-685.

45. Similä, M., Kouki, J., Martikainen, P. and Uotila, A. 2002. Conservation of beetles in boreal pine forests: the effects of forest age and naturaleness on species assemblages. Biol. Conserv. 106, 19-27.

46. Jentoft, S. 1999 Commons in a Cold Climate Coastal Fisheries and Reindeer Pastoral ism in Northern Norway: the Co-Management Approach. Parthenon, New York.

47. Osherenko, G. 2001. Indigenous rights in Russia: is title to land essential for cultural survival? Georgetown Int. Environ. Law Rev. 13, 695-734.

48. Carlsson, L. 2003. The strategy of the commons: history and property rights in central Sweden. In: Navigating Social-Ecological Systems. Berkes, F., Colding, J. and Folke, C. (eds). Cambridge University Press, Cambridge, pp. 116-131.

49. Angelstam, P., Bergman, P. 2004. Assessing landscapes for the maintenance of forest biodiversity - a pilot study using forest management plans. Ecol. Bull. 51.

50. Bjorklund, I. 1990. Sami reindeer pastoralism as an indigenous resource managemen system in northern Norway: a contribution to the common property debate. Dev. Change 21, 75-86.

51. Lewis, H.T. and Ferguson, T.A. 1988. Yards, corridors and mosaics: how to burn a boreal forest. Human Ecol. 16, 57-77.

52. Berkes, F. 1998. Indigenous knowledge and resource management systems in the Canadian subarctic. In: Linking Social and Ecological Systems. Berkes, F. and Folke, C. (eds). Cambridge University Press, Cambridge, pp. 98-128.

53. Balikci, A. 1968. The Netsilik Eskimos: Adaptive processes. In: Man the Hunter. Lee, R.B. and DeVore, I. (eds). Aldine, Chicago, pp. 78-82

54. Krupnik, I. 1993. Arctic Adaptations: Native Whalers and Reindeer Herders of Northern Eurasia. University Press of New England, Hanover and London.

55. Freeman, M.M.R. 1996. Identity, health and social order. In: Human Ecology and Health: Adaptation to a Changing World. Foller, M.L. and Hansson, L.O. (eds). GoteHealth: Adaptation to a Changing Wort
borg University. Goteborg, pp. 57-71.

56. Folke, C., Berkes, F. and Colding, J. 1998. Ecological practices and social mechanisms for building resilience for sustainability. In: Linking Social and Ecological Systems. Berkes, F. and Folke, C. (eds). Cambridge University Press, Cambridge, pp. 414-436.

57. Feit, H.A. 1973. Ethno-ecology of the Waswanipi Cree; or how hunters can manag their resources. In: Cultural Ecology. Cox, B. (ed.). McClelland and Stewart, Toronto, pp. $115-125$

58. Feit, H.A. 1987. North American native hunting and management of moose populations Swedish Wildlife Research Vitlrevy Suppl. 1, 25-42.

59. Berkes, F. 1999. Sacred Ecology. Traditional Ecological Knowledge and Resource Management. Taylor \& Francis, Philadelphia and London.

60. Berkes, F. 1982. Waterfowl management and northern native peoples with reference to Cree hunters of James Bay. Musk-Ox 30, 23-35.

61. Fast, H., Mathias, J. and Banias, O. 2001. Directions toward marine conservation in Canada's Western Arctic. Ocean Coastal Manage. 44, 183-205.

62. Downie, D. and Fenge, T. (eds). 2003. Northern Lights Against POPs: Combatting Toxic Threats in the Arctic. McGill-Queen's University Press. Montreal and Kingston.

63. Berkes, F. 2002. Cross-scale institutional linkages for commons management: Perspectives from the bottom up. In: The Drama of the Commons. Ostrom, E., Dietz, T., Dolsak, N., Stern, P.C., Stonich, S. and Weber, E.U. (eds). National Academy Press, Washington N., Ster.

64. Pastor, J., Dewey, B., Moen, R., Mladenoff D.J., White, M. and Cohen, Y. 1997. Spatial Patterns in the Moose-Forest-Soil Ecosystem on the Isle Royale, Michigan, Ecol. Applic. 8, 411-424.

65. Crépin, A.-S. 2002. Management challenges for multiple-species boreal forests. In Tackling the Economics of Ecosystem. Dissertations in Economics 2002:6, Stockholm University.

66. Crépin, A.-S. 2003. Multiple species boreal forests - what Faustmann missed, Environ Resource Econ. 26, 127-148

67. Dasgupta, P. and Mäler K.G. (eds). 2003. The Economics of Non Convex Environments, Environ. Resource Econ. 26 (Special Issue, Dec.).

68. Karvonen, L. 2000. Guidelines for Landscape Ecological Planning. Vantaa: Metsähallitus.

69. Pauly, D., Christensen, V., Guénette, S., Pitcher, T.J., Rashid Sumaila, U., Walters, C.J. Watson, R. and Zeller, D. 2002. Towards sustainability in world fisheries. Nature 418 , 689-695

70. Batisse, M. 1997. Biosphere reserves - a challenge for biodiversity conservation and Regional development. Environ. 39, 7-33.

71. Jongman, R.H.G., Troumbis, A.Y. and Nowicki, P.L. (eds). 1996. The Wider Landscape for Nature Conservation: Ecological Corridors and Buffer Zones. Final draft MN2.7 sub-project report. European Centre for Nature Conservation, the Netherlands.

72. Thorell, M. 2003. Forest Conservation Strategy in Southern Sweden: the Role of Small Reserves and Buffer Zones. PhD thesis, Göteborg University, Göteborg, Sweden.

73. Olsen, S. 1988. Arealkrav og behov av for buffersoner ved vern av urort barskog. Dis-
. Olsen, S. 1988. Arealkrav og behov av for bufferso
sertation, Norwegian Forest Research Institute, Ås.

74. Carlsson, L. 2000. Policy networks as collective action. Policy Stud. J. 28, 502-520

75. Krupnik, I. and Jolly, D. (eds). 2002. The Earth Is Faster Now: Indigenous Observation of Arctic Environmental Change. Arctic Research Consortium of the United States, Fair-

76. Folke, C., Carpenter, S.R., Elmqvist, T., Gunderson, L., Holling, C.S. and Walker, B 2002. Resilience and sustainable development: building adaptive capacity in a world of transformations. Ambio 31, 437-440.

77. We thank Jan Bengtsson, Magnus Nyström and Fredrik Moberg for many stimulating discussions about dynamics reserves. Thomas Elmqvist and Carl Folke have been supported by Formas and Vetenskapsrådet.

\section{Corresponding author: \\ Professor Thomas Elmqvist \\ Department of Systems Ecology, \\ Stockholm University, \\ SE-106 91 Stockholm, Sweden.}

\section{thomase@ecology.su.se}

